\title{
Kullanım Sürecinde Değerlendirilmesi, Malatya Kent Meydanları Örneği
}

\section{Sima POUYA ${ }^{* 1}$, Burak SEKMAN ${ }^{1}$ \\ ${ }^{1}$ Inönü Üniversitesi, Güzel Sanatlar ve Tasarım Fakültesi, Peyzaj Mimarlığı Bölümü, Malatya, Türkiye}

Öz: Kent meydanları, yoğun ve oldukça hareketli kent yaşamının en önemli öğelerinden biridir. Gün içerisinde kentliler tarafından dinlenmek, eğlenmek, ticari faaliyetler, toplanmak gibi çeşitli amaçlar için kullanılmaktadır. Her gruptan insanı buluşturan, sosyal iletişimin sağlandığı mekanlar olarak kentin ve kent yaşamının önemli ve ayrılmaz bir parçasıdır. Meydanlar planlanırken üstlendiği bu önemli roller göz ardı edilmemelidir. Erişilebilirlik, sosyallik, etkinlikler ve konfor diğer kamusal alanlarda olduğu gibi kent meydanlarında başarılı bir mekan olması için sahip olması gereken dört ana özelliktir. Kentsel mekanlarda başarımın sağlanması için planlama ve tasarım sürecinde alınan kararların kullanım sürecinde de işlemesi gerekir. Mekanların kullanım sürecinde başarıyı değerlendirmemizi sağlayan yöntemlerden biri de "Kullanım Sürecinde Değerlendirme (KSD) Yöntemi" dir. Bu çalışmada da meydanların çeşitleri, özellikleri, tasarım ve planlama kriterleri irdelenmiş ve Malatya'da bulunan ve günlük olarak yoğun bir şekilde kullanılan farklı kimliklere sahip Yeni Cami Meydanı, Hükümet Meydanı ve Kernek Meydanı KSD yöntemi kullanılarak değerlendirilmiştir. Çalışma sonucuna göre meydanların, fiziksel, algısal ve işlevsel olarak geliştirilmesi gerekmektedir. Her üç meydanın fiziksel, işlevsel ve algısal özelliklerinin geliştirilmesi, mekanın konfor, imaj, sosyallik ve erişilebilirlik özeliklerini güçlendirecektir.

Anahtar Kelimeler: kentsel mekanlar, meydan tasarımı, kent kullanıcıları

\section{Post Occupancy Evaluation, Example Of Malatya Urban Square}

\begin{abstract}
City squares are one of the most important elements of busy and highly active urban life. During the day, it is used by citizens for various purposes such as resting, having fun, commercial activities and gathering. It is the most important integral part of the city and city life, where social communication is provided, bringing together people from every group. These important roles should not be overlooked when planning squares. Accessibility, sociability, events and comfort are the four main features that a public must have in order to be a successful venue in other public spaces. In order to ensure success in urban spaces, the decisions taken in the planning and design process must also work in the use process. One of the methods that provide us to evaluate the performance of the locations during the usage process is the "Post Occupancy Evaluation (POE) Method". In this study, the types, properties, design and planning criteria of the squares were examined and the Yeni Cami Meydanı, Hükümet Meydanı and Kernek Meydanı, which have different identities used in Malatya, were evaluated using POE method. According to the results of the study, the squares need to be developed physically, perceptually and functionally. Improving the physical, functional and perceptual features of all three squares will strengthen the comfort, image, sociability and accessibility features of the space.
\end{abstract}

Keywords: urban spaces, square design, urban users

\section{GíRiş}

Insanlar tarih boyunca birlikte yaşamışlardır, antik dönemden günümüze kadar olan süreçte bu birlikte yaşama intiyacı neticesinde de kent yerleşimlerini oluşturmuşlardır. Kentler insanların ekonomik, sosyal, kültürel ve barınma gibi ihtiyaçlarını karşıladıkları yerleşim alanlarıdır (Bulmaz ve Alp, 2018). Kentlerde yaşayan insanların ihtiyaçları kentleri biçimlendiren önemli etkenlerden biri olmuştur.

Insanların barınma, ekonomik, güvenlik gibi temel ihtiyaçları dışında sosyalleşmeye de ihtiyaçları vardır. İnsanların rekreasyonel ihtiyaçlarına cevap veren park alanları, dinlenme ve eğlence alanları, promenatlar ve rekreasyonel imkanlar dışında birçok işlev üstlenen meydanlar kentlerin en önemli mekanlarındandır. Meydanlar kentin kültürünü ve kimliğini yansıtan en önemli kamusal dış mekanlardır (Durak, 2018). Kent yaşamında gün içerisinde istemsizce karşılaşmaların ve rastlantıların yaşandığı meydanlar, kamusal iletişimin sağlandığı çok sayıda insanın bir araya gelerek etkileşimde bulunduğu mekanlardır (Erdönmez ve Akı, 2005).
Kentliler ve kent için önemli mekanların başında gelen, insanların gün içerisinde yoğun olarak kullanıldığı çoğu ihtiyaçlarını giderdikleri meydanlar, planlanırken ve tasarlanırken de insan ve kent odaklı düşünülmelidir. İnsan ihtiyaçlarına cevap verirken kentin kimliğini kültürünü de yansıtmalıdır. Lynch, düğüm noktası görevindeki meydanları, "kentin insanlar tarafından algılanıp okunabilmesinde ve kente bir imge kazandırılmasında en önemli beş ögeden biri" olarak tanımlamıştır (Akpınar, 2013).

Moughtin, meydanları kentsel tasarımın en önemli elemanları olarak tanımlamış ve meydanların binalarla çevrelenmiş alanlar olduğunu, yapıların algılanmasında avantaj sağladığını ifade etmiştir. Yapılarla sınırlanmış, sokaklarla çevrelenmiş ya da onlarla bağlantı içindeki bu

*Sorumlu Yazar: sima.pouya@inonu.edu.tr

Geliş Tarihi: 10 Mart 2020

Kabul Tarihi: 18 Kasım 2020 
alanlar, çeşme, bank, bitki, koruyucu elemanlar gibi çeşitli öğeler içererek, insanların ilgisini çekmekte ve halkın sosyalleşmesini sağlamaktadır (Semerci, 2014). Meydanlar, kentsel yaşamın bir araya geldiği alanlardır (Wolfrum, 2014). Kentsel yaşamda büyük bir öneme sahip olan bu mekanların birçok işlevi olmalıdır. Meydanlar, pazar yerleri gibi ticari faaliyetlerin yanı sıra kütüphane, tiyatro, kafeler, gençlik merkezleri gibi kültürel faaliyetleri de içerisinde barındırmalı ve günün yirmi dört saati kullanılan mekanlar olmalıdır (Krier, 1979).

Bir alana meydan vasfı kazandırmak için en önemli konuların başında konum gelmektedir. Kentlerin merkezi olarak kabul edilen meydanlar bulundukları bölgelerde de merkezi olmalıdır. Meydanlar gibi açık kamusal alanlarda istenilen başarının sağlanması mekanın formuyla yani biçimiyle de doğrudan alakalıdır. Mekanın formu bulunduğu alanın topografik ve fiziki özelliklerine uygun olmalıdır. Meydanın formu belirlenirken meydanın çevresi ile olan ilişkisine uygun bir biçimde olmalıdır (Durak, 2018).

Meydanların ve yaya bölgelerinin planlamasında, gelişen kent merkezlerinde yer alan meydanların yeniden düzenlenmesinde, yapı-çevre ilişkilerinde proporsiyon önemli bir faktördür. Düzensiz uygulamalar ve kentin gelişimi dikkate alınmadan yapılan planlama çalışmaları sonucunda meydan olarak ayrılmış alanların zaman içinde kentin gelişmesine göre yapılaşmaya dönüştüğü görülmüştür. Bundan dolayı kent meydanlarının çevresinde planlanacak olan bitkisel materyal ve konstrüktif elemanlar bu meydana olabilecek herhangi bir olumsuz müdahaleyi önleyici nitelikte olmalıdır (Önder ve Aklanoğlu, 2002). Bu tür halka açık yerler tam anlamıyla temel ilkelere göre tasarlandığında ve bir yer hissi ile iç içe olduklarında ek bir sembolik anlam kazanırlar (Moughtin, 1992).

Meydanlar en önemli kamusal alanlardan birisidir ve diğer kamusal alanlar da olduğu gibi bu mekanların başarılı olması için bazı kriterleri sağlaması gerekir. "Project for Public Spaces" adlı sivil toplum kuruluşuna göre mekanı başarılı kılan dört ana özellik vardır. Bunlar: etkinlikler, erişilebilirlik, sosyallik ve konfordur (Akpınar, 2013).

Project for Public Space (PPS)'e göre başarılı bir mekan genel olarak erişilebilir ve çevresindeki mekanlarla güçlü bağlantıları olan, kullanıcıların gözünde iyi bir kimliğe sahip olan ve konforlu, kullanıcıların vakit geçirebileceği kullanımlar ve aktiviteler barındıran, bu mekanı kullanan insanların birbirleri ile sosyalleşmelerine imkan tanıyan mekanlardır (Çizelge 1) (İnan, 2008). PPS kentsel mekanın kalite kriterlerini değerlendirdikten sonra bu dört ana özelliğin soyut bileşenlerini ve göstergelerini belirtmişler, böylece kentsel mekanın kalitesinin değerlendirilmesi için bir altlık oluşturmuştur (Karaçor ve Çıracı, 2016).

Çizelge 1. Bu çizelge "Project for SPACE (PPS)" tanımladığı mekan kalitesi özelliklerine göre oluşturulmuştur (Uzgoren, 2016)

\begin{tabular}{|c|c|c|c|}
\hline \multicolumn{4}{|c|}{ KENTSEL MEKAN KALITE KRITERLERi } \\
\hline Anahtar Özellikler & & Unsurlar & Göstergeler \\
\hline \multirow{5}{*}{ Kullanım ve Aktiviteler } & Eğlenceli & Şenlikli & Yerel İşletme Sahipleri \\
\hline & Aktif & Sürdürülebilir & Arazi Kullanım Deseni \\
\hline & Can Alıcı & Gerçek & Emlak Değrleri \\
\hline & Özel & Kullanışlı & Kira Düzeyi \\
\hline & Özgün & & Perakende Satış \\
\hline \multirow{5}{*}{ Sosyallik } & Çeşitlilik & Gurur & Çocuk, Kadın Ve Yaşlı Sayısı \\
\hline & Yönetim & Cana Yakın & Sosyal Ağlar \\
\hline & İşbirliği & Etkileşimli Samimi & Gönüllülük \\
\hline & Komşuluk & & Akşam Kullanımı \\
\hline & & & Sokak Hayatı \\
\hline \multirow{5}{*}{ Konfor ve İmaj } & Güvenli & Çekici & Suç Oranları \\
\hline & Temiz & Tarihi & Sanitasyon Hizmetleri \\
\hline & Yeşil & Ruhu Olan & Yapı Durumu \\
\hline & Yürünebilir & Cazip & Çevresel Veriler \\
\hline & Oturulabilir & & \\
\hline \multirow{5}{*}{ Erişim ve Bağlantılar } & & & Trafik Verileri \\
\hline & Süreklilik & Yürünebilir & Mod Ayrımları \\
\hline & Yakınlık & Erişilebilir & Transit Kullanım \\
\hline & Bağlantılı & Elverişli/Uygun & Yaya Hareketleri \\
\hline & Okunabilir & & Park Alanı Kullanım Deseni \\
\hline
\end{tabular}


Planlama ve tasarım sürecindeki değerlendirmenin yanı sıra kullanım sürecindeki değerlendirme de kent meydanlarının başarısını değerlendirme açısından önemlidir. Bu çalışmanın amacı Malatya kentinde bulunan ve yoğun olarak kullanılan meydanların kullanıcıların da katılımıyla meydanların kullanım sürecinde değerlendirilmesidir. Meydanların fiziki performansı ve işlevsel performansını ortaya koymak için çalışmada "Kullanım Sonrası Değerlendirme" (KSD) metodu kullanılmıştır. KSD metodunun avantajı yapıların veya mekanların inşa edilip kullanılmaya başlamasından sonra da kullanıcıların da katılımıyla mekan kullanılırken değerlendirmeye ve mekanın başarısını saptamaya olanak sağlamasıdır (Pouya ve Akıncı, 2019; Pouya, 2016). Kent meydanlarının kullanım sürecinde değerlendirip iyileştirilmesi kentlilerin yaşamını kolaylaştıracak ve bu mekanların başarısını arttıracaktır. Bu çalışmada Malatya kent meydanlarında kullanıcı görüşlerinden yararlanarak meydanların performanslarının araştırılması ve bu mekanların başarısının değerlendirilmesi için KSD metodu kullanılmıştır.

\section{MATERYAL VE YÖNTEM}

\section{Materyal}

Bu çalışmanın materyalini Malatya kentinde bulunan meydanlar oluşturmaktadır. Malatya kentinin en yoğun kullanılan mekanlarından olan Hükümet Meydanı, Kernek Meydanı ve Yeni Camii Meydanı çalışma alanı olarak belirlenmiştir (Şekil 1). Çalışma alanı olarak belirlenen
POUYA S, SEKMAN B

meydanların kent hafızasında önemli yere sahip olması, meydanların kentin en merkezi konumunda olması ve meydanlarının birbiri ile bağlantılı bir durumda olması bu mekanların çalışma alanı olarak belirlenmesinde etkili olmuştur.

\section{Hükümet Meydanı}

Hükümet meydanı, Malatya halkının çarşı olarak adlandırdıkları kent merkezinin odağında yer almaktadır (Şekil 2). Meydanın üç tarafı caddelerle çevrili bir durumda olup kentin en işlek ve uzun caddelerinden olan inönü Caddesi ile Fuzuli Caddesi tarafından çevrelenmektedir. Meydanın altında Malatya Kapalı Çarşı'sı bulunmaktadır. Meydanın hemen güney yönünde meydanı kimliklendiren Hükümet Konağı (Malatya Valiliği) bulunmaktadır. Meydanın içerisinde aslen Malatyalı olan Cumhuriyet'in ilk başbakanı İsmet İnönü'nün heykeli bulunmaktadır.

\section{Yeni Cami Meydanı}

Yeni Cami, 3 Mart 1894 yılındaki büyük depremde yıkılıp büyük hasar gören $\mathrm{HaCı}$ Yusuf Cami'nin yerine yapılmıştır (Şekil 3). Gerek inşa edilirken yaşanan olaylar, zorluklar gerekse konumu bakımından kent belleğinde önemli yer edinmiştir. Klasik olduğu gibi merkezi konumda bulunan caminin avlusu ve çevresi yoğun kullanım nedeniyle meydan işlevi kazanmıştır. Meydanın İnönü Caddesinin çeperinde bulunması ve aynı zamanda çevresinin işhanları ve ticaret alanları ile çevrili olması mekandaki insan etkinliğini arttıran önemli etkenlerdendir.
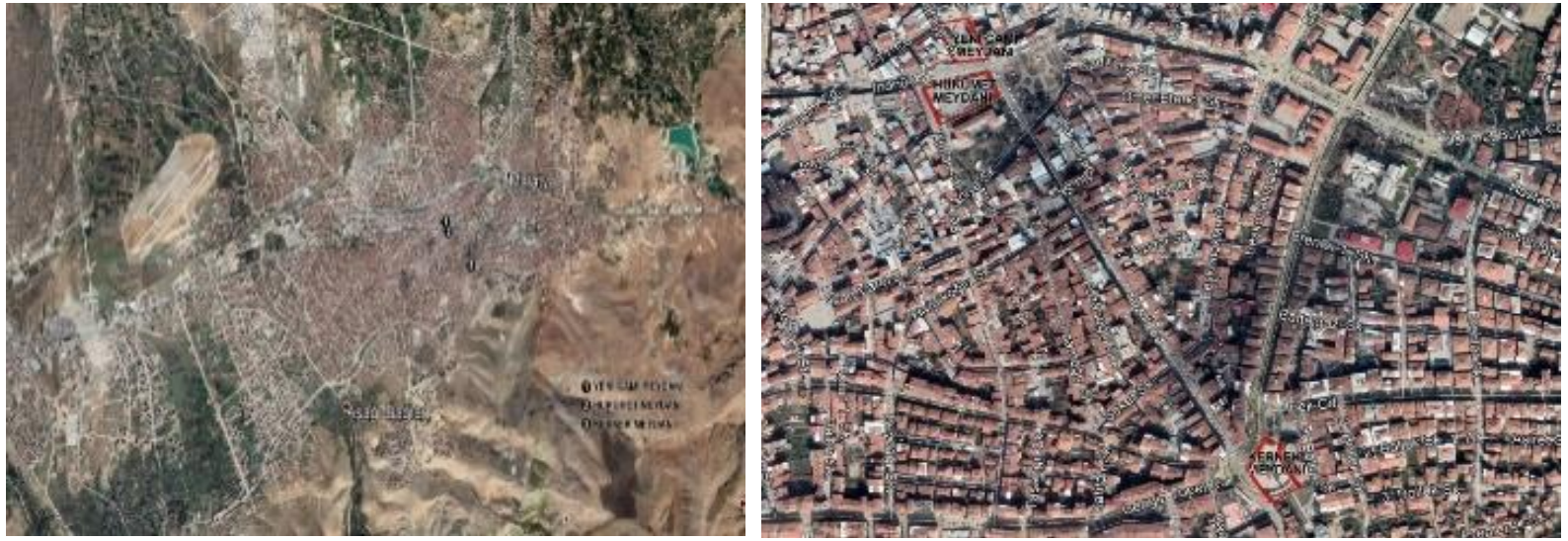

Şekil 1. Malatya Yeni Cami Meydanı, Hükümet Meydanı ve Kernek Meydanın konumu (Google Earth, 2019).
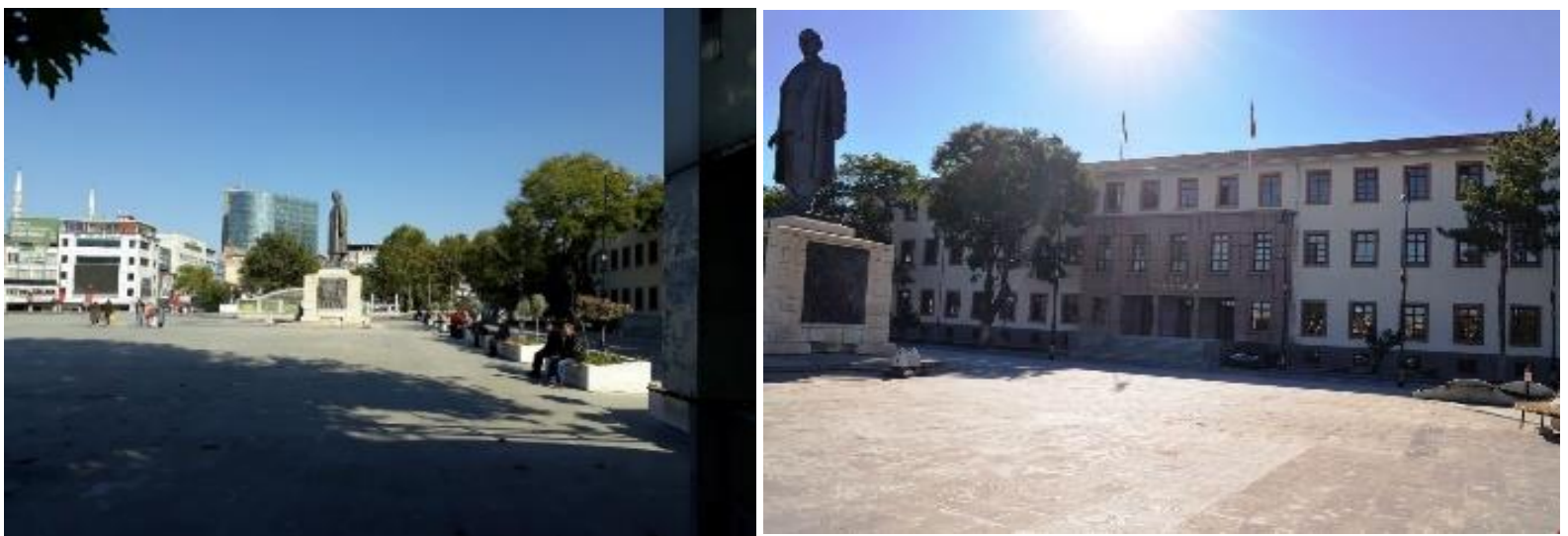

Şekil 2. Hükümet Meydanı Malatya 


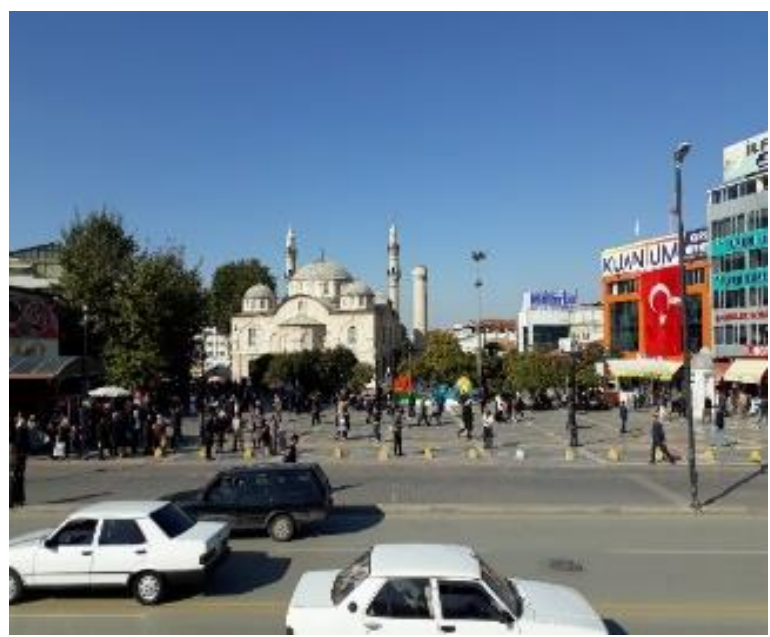

Şekil 3. Yeni Cami Meydanı

\section{Kernek Meydanı}

Fuzuli Caddesi ile Hükümet Meydanı'na ve İnönü Caddesine bağlanan Kernek Meydanı, özellikle Malatya tarihinde ve kültüründe çok önemli bir yere sahip olan Derme Kanalı'nın da bu alandan geçmesiyle kent halkı için önemli bir yere sahiptir (Şekil 4). Meydan, Kanalboyu olarak adlandırılan kafelerin yoğun olarak bulunduğu ve kent halkı tarafından yoğun olarak kullanıldığı caddenin başında bulunmaktadır. Meydan güney yönünde uzayan Şelale Parkı ile bütünleşik bir haldedir. Kent müzesi ve Kernek Cami'si de bu alanda bulunan önemli yapılardandır. Meydandan Derme suyunun geçmesi ve mekanın kentlilerin anı mekanlarından biri olmasından dolayı kentin hafıza mekanlarından biridir.

\section{Yöntem}

Çalışma alanı olarak belirlenen meydanlarda kullanıcı görüşlerinden de yararlanarak olumlu ve olumsuz yönlerinin araştırılması ve bu mekanların başarımlarının değerlendirilmesi için KSD metodu kullanılmıştır. KSD yöntemi inşa edilmiş ve kullanılmakta olan yapıları ve mekanları sistemli bir şekilde değerlendirme süreci olarak

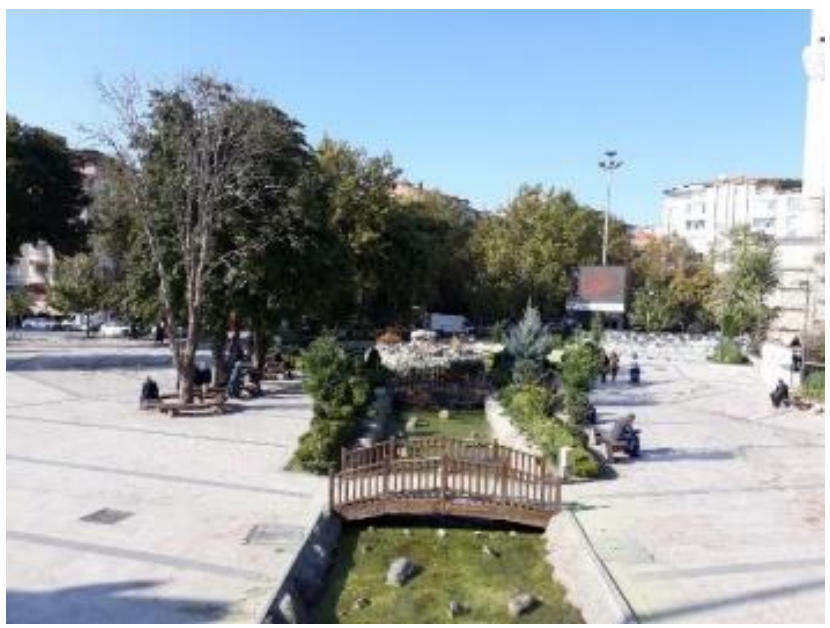

Şekil 4. Kernek Meydanı Malatya

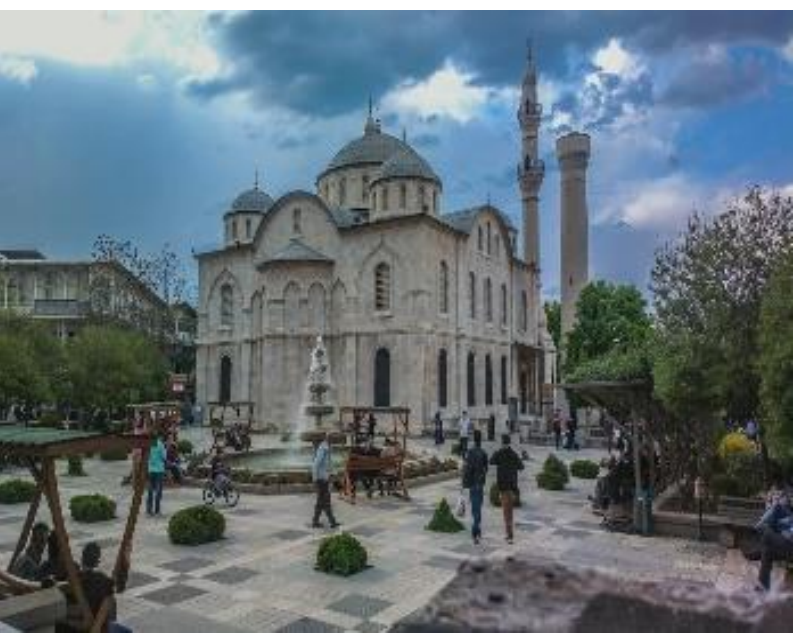

tanımlanmaktadır. Bu çalışmada KSD yöntemi kapsamında veri elde etmek için iki teknik kullanılmıştır. Bunlar gözlem ve anket tekniği olmuştur. Meydanların fiziksel durumu, işlevselliği ve mekan-kullanıcı arasındaki ilişkilerini incelemek için hafta içi ve hafta sonu belirli saatlerde gözlem çalışması yapılmıştır (Çizelge 2). Gözlem gerçekleştirilirken veriler notlar tutularak kayda alınmış ve meydanlar fotoğraflanmıştır.

Çizelge 2. Gözlem tarihleri ve saatleri

\begin{tabular}{llll}
\hline Tarih Mekan & $\begin{array}{l}\text { Yeni Cami } \\
\text { Meydanı }\end{array}$ & $\begin{array}{l}\text { Hükümet } \\
\text { Meydanı }\end{array}$ & $\begin{array}{l}\text { Kernek } \\
\text { Meydanı }\end{array}$ \\
\hline 22.11 .2019 & $08: 00-09: 30$ & $09: 30-11: 00$ & $08: 00-09: 30$ \\
Cuma & $17: 00-18: 30$ & $18: 30-20: 00$ & $17: 00-18: 30$ \\
24.11 .2019 & $08: 00-09: 30$ & $09: 30-11: 00$ & $08: 00-09: 30$ \\
Pazar & $17: 00-18: 30$ & $18: 30-20: 00$ & $17: 00-18: 30$ \\
29.01.2019 & $08: 00-09: 30$ & $09: 30-11: 00$ & $08: 00-09: 30$ \\
Cuma & $17: 00-18: 30$ & $18: 30-20: 00$ & $17: 00-18: 30$ \\
01.12.2019 & $08: 00-09: 30$ & $09: 30-11: 00$ & $08: 00-09: 30$ \\
Pazar & $17: 00-18: 30$ & $18: 30-20: 00$ & $17: 00-18: 30$ \\
\hline
\end{tabular}

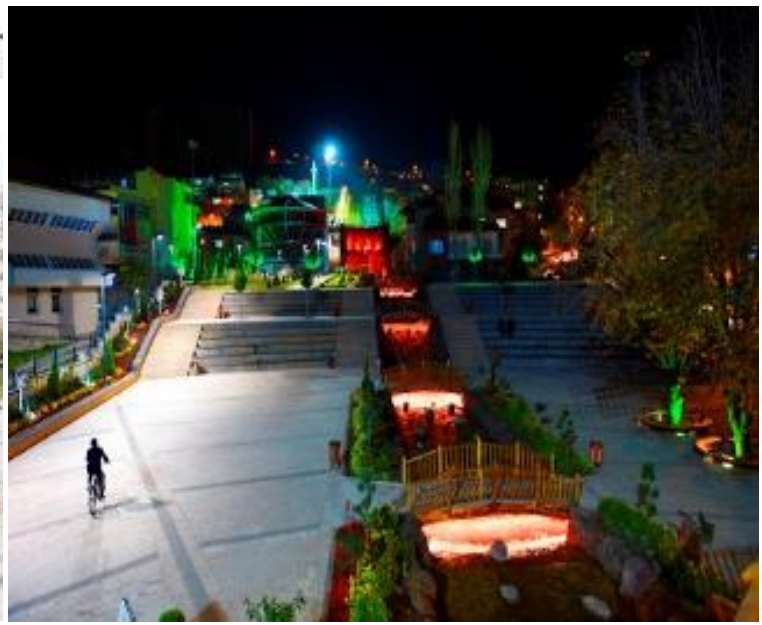


Çalışma alanının fiziksel, algısal ve işlevsel performansını değerlendirmek amacıyla alandaki 150 kullanıcıya anket çalışması yapılmıştır. Anket soruları kullanıcıların biyografık özellikleri yanında alanı ne için kullandıkları ve estetik, erişilebilirlik, yapı malzemeleri, bitkisel materyaller, donatı elemanları gibi özelliklerin değerlendirmesine yönelik soruları içermektedir. Anketler hafta içi ve hafta sonu öğlen saatlerinde bir anketör tarafından gerçekleştirilmiştir. Anket çalışması gerçekleştirilirken kullanıcılara soruların doğru veya yanlış bir cevabı olmadığı konularında bilgilendirilip soruları değerlendirirken özgün olmaları istenmiştir.

Gözlem ve anket çalışmaların gerçekleşmesinde ve elde edilen bulguların değerlendirmesinde PPS (Project for Space)'in tanımladığı kentsel mekan kalite kriterleri kullanılmıştır. Yapılan analizler sonrası elde edilen veriler SPSS programına işlenerek soruların frekanslarına bakılmıştır.

\section{BULGULAR TARTIŞMA}

Gözlem çalışmasından Elde Edilen Bulgular

Yapılan gözlem çalışmalarında çalışma alanı olarak belirlenen Yeni Cami Meydanı, Hükümet Meydanı ve Kernek Meydanı'nın farklı özelliklerde olup kullanıcıların bu mekanları kullanım amaçlarının farklı olduğu görülmüştür.

\section{Yeni Cami Meydanı}

Yeni Cami Meydanı'nın diğer iki meydana göre daha yoğun bir kullanıma sahip olduğu gözlenmiştir. Bunun temel sebeplerinden birisi kent içi ulaşımın sağlandığı toplu taşımanın merkezi durağının meydanın içerisinde bulunmasıdır. Gözlem sürecinde elde edilen verilere göre
POUYA S, SEKMAN B insanlar bu meydanı başka bir yere giderken geçiş güzergahı olarak, yine başka bir yere ulaşmak için otobüsleri kullanmak amacıyla, kent merkezinde ve kolay bulunabilir olmasından dolayı buluşmak için, ulaşımın kolay olması, dinlenmek, eğlenmek ve alışveriş yapmak için kullanmışlardır (Şekil 4).

Türk tarihinde sosyal yaşantının bir parçası olan camiler bu meydanda özelliğini sürdürmektedir. Genellikle yaşlı bireyler günlük olarak buraya gelip hem günlük ibadetlerini yapmakta, hem de ibadet saatleri dışında da bu mekanda diğer bireyler ile birlikte vakit geçirmektedirler (Şekil 4 ve 5).

Yeni Cami Meydanı içerisinde meydana ismini veren bir cami, bir adet çeşme, büfe, ağaç altı dinlenme alanları, süs havuzu ve şehir içi ulaşımın sağlandığı merkez otobüs durakları bulunmaktadır. Kullanıcıların görüşlerine göre meydanda kullanılan zemin kaplamasının havanın yağışı olduğu dönemlerde kayganlaşması yürüme konforunu olumsuz etkilemektedir.

\section{Hükümet Meydanı}

Yeni Cami Meydanı́nın karşısında bulunan Hükümet Meydanı, kullanıcılar tarafından özellikle buluşmak için ve başka bir yere giderken geçiş güzergahı olarak kullanılmaktadır. Dörtgen şeklinde olan meydanın 3 tarafı caddelerle çevrilidir. Meydanın güneyinde Malatya Valiliği bulunmaktadır. Meydan içerisinde kullanıcılar tarafından işaret öğesi olarak da kullanılan Türkiye Cumhuriyeti birinci başbakanı İsmet İnönü’nün heykeli bulunmaktadır.
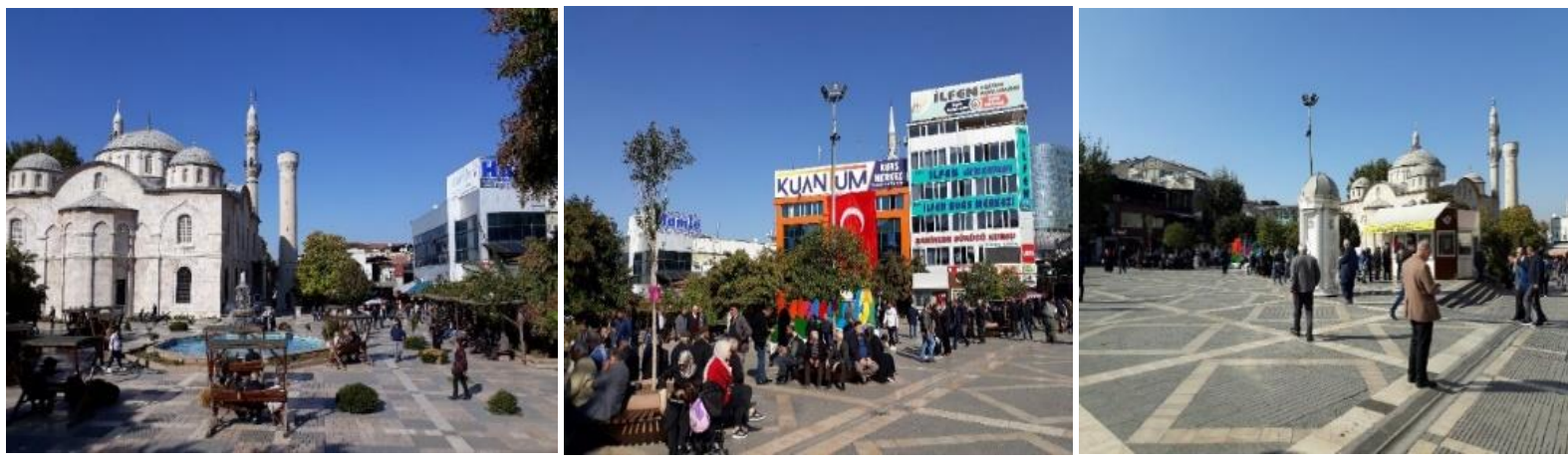

Şekil 4. Gözlem çalışması sırasında Yeni Cami Meydanı́ndan çekilen görüntüler
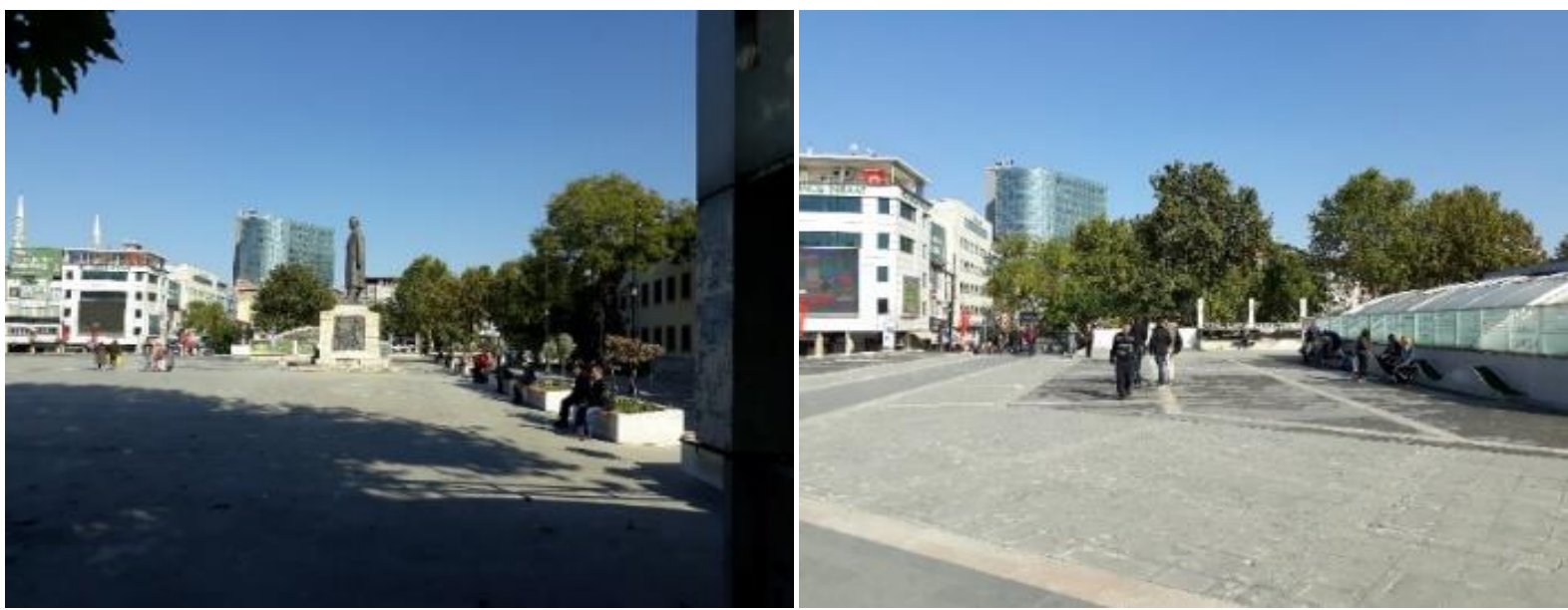

Şekil 5. Gözlem çalışması sırasında Yeni Cami Meydanı'ndan çekilen görüntüler 
Malatya Kapalı Çarşı'sının çatısı şeklinde olan meydan tamamen sert zeminden oluşmaktadır. Meydanda ağaç ve gölgelendirme elemanı bulunmamaktadır. Meydan içerisinde görme engelli kullanıcılar için kılavuz çizgiler bulunmamakta ve zeminde kullanılan malzemenin tek renk olması ve zeminde kot farklarının bulunması engelli bireylerin meydanı kullanırken zorlanmalarını sebep olmaktadır.

Gözlem süresi boyunca meydanda daha çok genç bireylerin vakit geçirdiği ve çoğu kullanıcının bu mekanı buluşma noktası olarak kullandığı gözlemlenmiştir. Meydan sabah saatlerinde daha yoğun olarak kullanılmakta ve akşam saatlerinde ise günün diğer saatlerine göre daha az kullanıldığı gözlemlenmiştir.

\section{Kernek Meydanı}

Kernek Meydanı, Hükümet Meydanı ve Yeni Cami Meydanı ile Fuzuli Caddesi aracılığıyla bağlantı sağlamaktadır. Kafeler caddesi şeklinde olan ve kentliler tarafından eğlence ve dinlenmek amacıyla yoğun olarak kullanılan Kanalboyu (Şehit Hamit Fendoğlu) Caddesinin başında konumlanması meydanın yoğun kullanımını arttırmaktadır (Şekil 6).

Meydan içerisinde amfi, dinlenme alanları, çeşme, su öğesi ve büfeler bulunmaktadır. Meydanın çevresinde bir camii ve kent müzesi bulunmaktadır. Şelale Parkı meydanın güneyinde meydanla bütünleşik halde Derme kanalı boyunca uzanmaktadır. Park içerisinde kafe, restoran, çeşme, tuvalet ve çocuk oyun alanı yer almaktadır. Kullanıcılar gün içerisinde akşam saatlerinde (18:00 ve sonrası) ve hafta sonlarında meydanda vakit geçirmektedirler. Meydan içerisinde ve meydana olan bağlantılarda görme engelliler için kılavuz çizgiler bulunmamaktadır. Meydan ve Şelale park arasındaki bağlantı merdivenler ile sağlanmakta ve rampa çözümlemesi bulunmamaktadır.

\section{Anketlerden Elde Edilen Veriler}

Hazırlanan anket soruları belirlenen çalışma alanlarında kullanıcılara uygulanmıştır ve elde edilen cevaplar SPSS programına işlenerek analiz edilmiştir.

Yeni Cami Meydanı Anket Verileri

Ankete katılanların \%30'u otomobil sahibi olmalarına rağmen, otomobil sahiplerinin \%40'ı toplu taşıma, \%33,3'ü ise yürüyerek meydana ulaşmayı tercih etmektedirler.

Katılımcılar \%8 ile en fazla Zafer Mahallesi'nden gelerek meydanı kullanmaktadır. Zafer Mahallesini \%6 ile Tandoğan, Orduzu, Kernek mahalleleri ve Fahri Kayahan bölgesi takip etmektedir. Kullanıcılar meydanı sırasıyla en fazla buluşmak $(\% 37,5)$, işe gitmek (\%20) ve dinlenmek $(\% 18,8)$ amacıyla kullanmaktadır. Ankette "diğer" seçeneğini işaretleyen kullanıcılar meydandaki otobüs duraklarını kullanmak amacıyla mekana geldiklerini belirtmişlerdir. Meydan \%54'lük oran ile en fazla 06:00 12:00 saatleri arasında kullanılmaktadır.

Kullanıcıların \%50'si bu meydanda canlılık hissettiklerini belirtmişlerdir. Ankete katılanların \%36,7'si akıllarında en çok su öğesi (çeşme, süs havuzu vs.) ve mimari yapının olduğunu belirtmiştirler. "Bu meydan sizi rahatsız edecek kadar gürültü mü?" sorusuna ise kullanıcıların $\% 56$ 'sı "hayır" cevabını vermiştir.

Katılımcıların \%32,2'si dinlenme alanlarını, \%20,9'u gölgelendirme elemanlarını ve $\% 18,3^{\prime}$ ü ise yapı malzemelerini (zemin döşemesi vs.) eksik bulmakta ve geliştirilmesini önermektedir. "Sizce meydanın en olumlu yönü nelerdir?" sorusunu ise \%34'ü boş bırakırken, \%28'i meydanın konumunun en olumlu yönü olduğunu belirtmektedir.

\section{Hükümet Meydanı Anket Verileri}

Hükümet Meydanı anket sonuçları: Anket sonuçlarına göre katılımcıların \%36'sı otomobil sahibidir, otomobil sahiplerinin \%55,6'sı meydana kendi araçları ile ulaşmayı tercih etmektedirler. Anket sonuçlarına göre kullanıcılar, meydanı en fazla 12:00-17:00 saatleri arasında kullanmışlardır ve meydana en fazla buluşmak için gelmektedirler. Ayrıca katılımcıların \%76'sı bu mekanda 30dk ve ya daha az vakit geçirdiklerini belirtmişlerdir. Meydanda katılımcıların \%42'si, canlılık, \%37'si ise ferahlık hissetmektedirler.

Insanların \%86'sı bu meydana ve/veya meydan içi erişilebilirliği yeterli bulurken, \%14'ü erişilebilirliği yetersiz bulmaktadır. Erişilebilirliği yetersiz bulanların \%27,8'i "engelli rampası bulunmamaktadır" ve "zeminde kot/yükselti farkı bulunmaktadır" cevaplarını vermişlerdir. Katılımcılara sorulan "Bu meydanda neleri eksik buluyorsunuz ya da gelişmesini istiyorsunuz?" sorusuna $\% 24,8$ oranında gölgelendirme elemanları, \%21,6 oranında dinlenme alanları ve \%20,3 oranında bitkisel elemanlar / yeşil alan varlığı cevapları verilmiştir.

\section{Kernek Meydanı Anket Verileri}

Anket çalışmasına katılan kullanıcıların $\% 26^{\prime}$ sı otomobil sahibi olduğunu, \%74'ü ise otomobil sahibi olmadığını belirtmiştir. Otomobil sahibi olan kullanıcıların $\% 53,8^{\prime} i$ meydana kendi otomobiliyle gelmeyi tercih etmektedir.

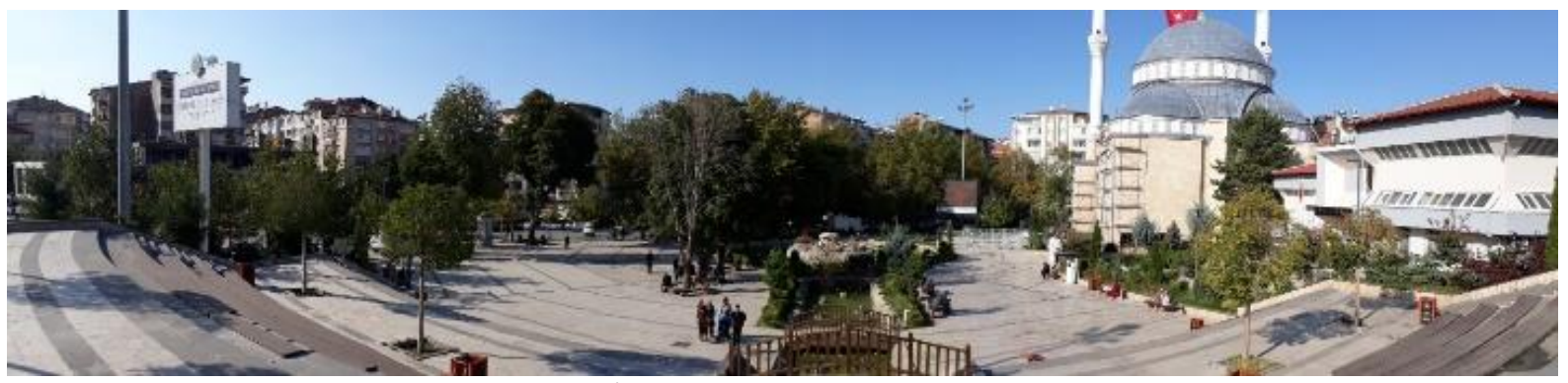

Şekil 6. Gözlem çalışması sırasında Yeni Cami Meydanı'ndan çekilen görüntüler 
Meydanı kullanan kullanıcıların \%12'si Kernek, \%8'i Beydağı ve \%6'sı Başharık, Hasan Varol, Sancaktar, Zafer Mahallesi bölgelerinde ikamet etmektedirler.

Katılımcıların \%34,7'si dinlenmek, \%33,7'si buluşmak ve \%16,3'ü de eğlenmek için Kernek Meydanı'na gelmektedir. Kullanıcıların \%54'ü 17:00-22:00 saatleri arasında, \%38'i ise 12:00-17:00 saatleri arasında meydanı kullanmaktadır. Kullanıcıların \%43,8'i bu mekanın kendilerine canlılık hissettirdiğini belirtirken, \%33,8'i ferahlık hissettirdiğini belirtmiştir.

"Bu meydana ve/ve ya meydan içinde erişilebilirlik yeterli midir" sorusuna evet cevabı verenlerin oranı \%82'dir. "Bu meydanda neleri eksik buluyorsunuz ya da gelişmesini istiyorsunuz" sorusuna cevap verenlerin \%29,1'i "temel ihtiyaçlar (tuvalet, çeşme vs.)", \%13,7'si "meydan içi erişim" ve "etkinlik/aktiviteler" cevabını vermişlerdir. Katılımcıların \%34'ü "Sizce meydanın en olumlu yönü nelerdir" sorusuna yanıt vermezken, \%32'si konum, \%14'ü su öğesi cevaplarını vermiştir.

\section{SONUÇ}

Meydanlar kent yaşamının en önemli parçalarından biridir. Kent yaşamında önemli roller üstlenen meydanlar insanlar için rekreasyonel imkanlar sunarken aynı zamanda toplanma alanı, ticaret merkezleri, pazar alanı, etkinlik ve aktivite alanları gibi çeşitli roller de üstlenmektedirler. Günlük yaşamda insanlar için büyük kolaylıklar sağlayan ve kent yaşamının bir parçası haline gelen meydanlar üstlendiği tüm bu rolleri her dönem yerine getirmeli ve insan ihtiyaçlarına sürekli cevap vermelidir. Sadece planlanırken değil planlandıktan sonra da kullanıcılar tarafından değerlendirilmelidir. Bu makalede yapılan gözlem ve anket çalışmalarında mekanın kullanıcı katılımıyla fiziksel, algısal ve işlevsel performansları değerlendirilmiştir. Project for Public Space (PPS)' tarafından kentsel mekanın kalitesinin değerlendirilmesi için hazırlanan altık bu çalışmada değerlendirilmiştir. Gözlem ve anket sonuçlarına göre çalışma alanların katile kriterleri Çizelge 3 'de belirlenmiştir.

Yeni Cami Meydanı ve Hükümet Meydanı'nın kentin en merkezi konumunda bulunması ve şehir içi toplu taşımanın sağlandığı otobüs duraklarının her iki meydanın çeperinde bulunması, bu mekanları 06:00-12:00 ve 12:00-17:00 saatleri arasında çok yoğun bir şekilde kullanılmasını sağlamaktadır. Meydanlar bu özelliği sayesinde sadece yakın çevresine değil kentin büyük bir bölümüne hizmet etmekte ve kentin çeşitli bölgelerinde ikamet eden insanlar tarafından yoğun olarak kullanılmaktadır.

Meydanların her yaştan insanlar tarafından kullanılması, insanlar arasında etkileşimin fazla olması, mekanın sosyallik özelliğini olumlu yönde etkilemektedir. Meydanların yürünebilir, oturulabilir, güvenli, çekici olması, güçlü bağlantılar, erişim, yoğun yaya hareketleri ve sanitasyon hizmetlerinin düzenli olarak yürütülmesi bu mekanların konfor, imaj ve erişim özelliklerini güçlendirmektedir.

Kullanıcılar ve gözlemci tarafından belirlenen eksiklerin giderilmesi, sosyallik, konfor, imaj, erişim, bağlantılar, kullanım ve aktivite özelliklerinin güçlendirilmesi meydanlarının başarısını arttıracak ve insan ihtiyaçlarına cevap veren dinamik mekanlar haline getirecektir.
Meydanlar tasarlanırken alanın ve kullanıcıların analizleri iyi yapılmalı, tasarım süreci bu doğrultuda ilerlemelidir. Tasarım sürecinde kullanıcıların sürece dahil edilmesi tasarımın başarısını olumlu yönde etkileyecektir. Meydanlar kentin kültürünü yansıtmalı, kullanıcıların ihtiyaçlarına cevap vermeli ve çevresi ile uyum içerisinde olmalıdır. Meydanda kullanılan materyaller çevre şartlarına dayanıklı olmalı ve kullanıcıların konforlarını olumsuz etkilememelidir. Yaşayan bir mekan olan meydanlar fiziksel ve işlevsel performanslarının yanı sıra estetik olarak da kullanıcıları tatmin etmelidir. Diğer kentsel mekanlarda olduğu gibi meydanlarda da erişim, hem meydana ulaşırken hem de meydan içerisinde her yaş grubu ve her fiziksel özellikteki bireyler için sağlanmalıdır.

\section{KAYNAKLAR}

Akpınar A (2013) Kentsel Açık Alanlar: Başarılı Bir Kentsel Açık Alan Için Gerekli Olan Kriterler Nelerdir. Peyzaj Mimarlığı 5. Kongresi. 14-17 Kasım 2013, Adana.

Altınçekiç S, Kart N (2000) Kentsel Tasarım Sürecinde Meydanlar. İstanbul Üniversitesi Orman Fakültesi Dergisi, 50(2): 111-120.

Bulmaz M (2018) Hakkâri Kent Meydanı: Mevcut Durumun Değerlendirilmesi ve Kullanıcıların Katılımı. Yüksek Lisans Tezi, Van Yüzüncü Yıl Üniversitesi, Fen Bilimleri Enstitüsü, Van.

Çubukcu C (2007) Kent Meydanlarının Simgesel İşlevleri Bakımından Antalya Cumhuriyet Meydanı Ve Çevresi Örneğinde Değerlendirilmesi - Geliştirilmesi Ve Bilgisayar Destekli Görsel Analizi. Yüksek Lisans Tezi, Ege Üniversitesi, Fen Bilimleri Enstitüsü, İzmir.

Durak H (2018) Tarihi Kent Meydanları Ve Donatılarının Peyzaj Mimarlığı Açısından İrdelenmesi; Sultanahmet Meydanı Örneği. Yüksek Lisans Tezi, Süleyman Demirel Üniversitesi, Fen Bilimleri Enstitüsü, Isparta.

Erdönmez E, Abay E (2018) Roma Popolo Meydanı Bağlamında Kamusal Mekan Kalitesinin Ölçülmesi. Kent Akademisi, 11(1): 44-59.

Erdönmez E, Akı A (2005) Açık Kamusal Kent Mekanlarının Toplum Ilişkilerindeki Etkileri. Megaron, 1(1): 67.

İnceoğlu K (2007) Kentsel Açık Mekânların Kalite Açısından Değerlendirilmesine Yönelik Bir Yaklaşım: İstanbul Meydanlarının Incelenmesi". Doktora Tezi, Yıldız Teknik Üniversitesi. Fen Bilimleri Enstitüsü, İstanbul.

Kamberov A (2016) Bir Kamusal Açik Alan Olarak Meydan Kullanimini Etkileyen Kararlarin Kullanicilar Tarafindan Değerlendirilmesi: Bakü Azadlik Meydani Örneği, Doktora Tezi, İstanbul Aydin Üniversitesi, Fen Bilimleri Enstitüsü, İstanbul.

Kocaman Ö (2018) Bir Kamusal Mekan Olarak Meydanın Çocuk Gözüyle Değerlendirilmesi: Türkiye, Isparta İli, Hükümet Meydanı Örneği. Yüksek Lisans Tezi, İstanbul Teknik Üniversitesi, Fen Bilimleri Enstitüsü, İstanbul.

Krier R, Rowe C (1979) Urban Space. London: Academy Editions

Moughtin C (1992) Urban Design: Street And Square. Buttenvorth Architecture Press, Oxford. 
Çizelge 3. Çalışma alanı olan Project for Public Space (PPS)'ın kentsel mekan kalite kriterlerine göre değerlendirilmesi

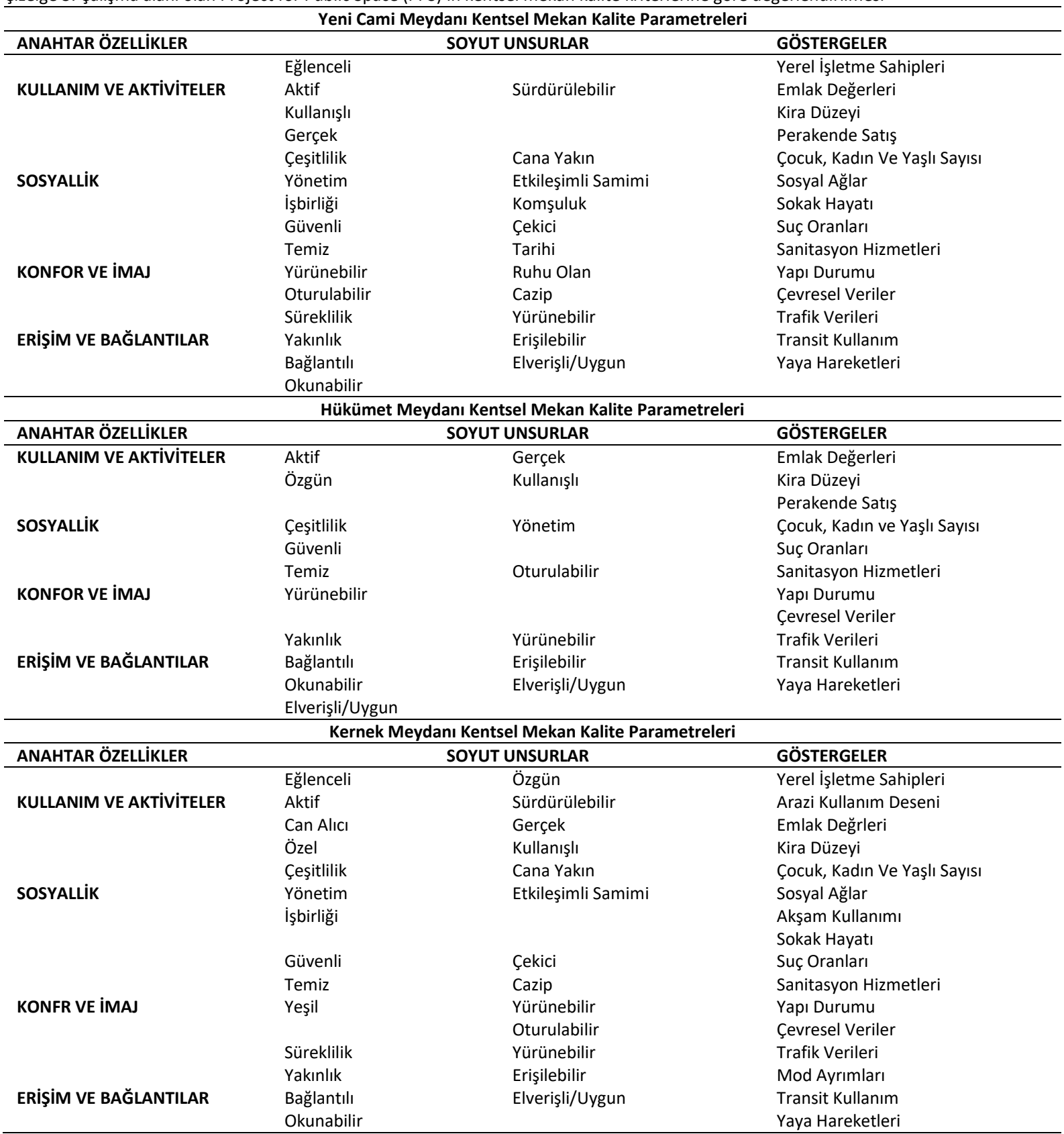

Kuyucu F, Vatan M (2017) Kullanim Sonrasi Değerlendirme Yöntemi: Gaziantep Hasan Kalyoncu Üniversitesi Öğrenci Yurtlari Örneği. İstanbul Aydın Üniversitesi Dergisi, 9 (1): 41-61.

Önder S, Aklanoğlu F (2002) Kentsel Açik Mekan Olarak Meydanlarin Irdelenmesi. Selcuk Journal Of Agriculture And Food Sciences, 16(29): 96-106.

Özer M, Ayten M (2005) Kamusal Odak Olarak Kent Meydanları. Planlama, 3: 96-103.

Pouya S, Akıncı ì (2019) Mimarlıkta Peyzaj Tasarımı, Nobel Akademik Yayıncılık, Bölüm Adı: Kullanım Sonrası Değerlendirme Metodu, Malatya Kenti Fahri Kayhan
Bölgesinde Bulunan Açık Yeşil Alanlar Örneği. 481503.

Pouya S (2016) Ortopedik Engelli Çocukların Iyileştirilmelerine Yönelik Planlama Yaklaşımı: Odtü Eymir Gölü Örneği (Ankara), Doktora Tezi, Karadeniz Teknik Üniversitesi. Fen Bilimleri Enstitüsü, Trabzon.

Semerci F (2014) Meydanların Işlevsellik Analizi: İstanbul Tarihi Yarımada Örneği, Doktora Tezi, Selçuk Üniversitesi. Fen Bilimleri Enstitüsü, Konya.

Şahin G (2018) Farklılaşan Sosyo-Ekonomik Yapının Meydanlardaki Kullanıcı Tercihi Ve Meydan Tasarımına Etkisinin Değerlendirilmesine Yönelik 
Yöntem Önerisi: Bursa Örneği. Yüksek Lisans Tezi, İstanbul Teknik Üniversitesi, Fen Bilimleri Enstitüsü, İstanbul.

Şavklı F, Yılmaz T (2013) Kent Meydanı Kullanım Nedenlerinin Antalya Cumhuriyet Meydanı Örneğinde Irdelenmesi. Türkiye Ormancılık Dergisi, 14(2): 138142.

Uzgören G, Müyesser E (2017) A Comparative Study On The Relationship Between Quality Of Space And Urban Space Activities In The Public Open Spaces/Kamusal Açık Alanlarda Mekan Kalitesi Ve Kentsel Mekan Aktiviteleri İlişkisi Üzerine Karşılaştırmalı Bir Inceleme. Megaron, 12(1): 41-56.
Wolfrum S (2014) Squares: Urban Space in Europe.

Yıldız A (2011) Tarihsel Birikime Sahip Kentsel Açık Alanların Dinamizmi-Isstanbul Kent Örneği; Beyazıt Meydanı, Sultanahmet Meydanı Ve Taksim Meydanı, Doktora Tezi, İstanbul Teknik Üniversitesi. Fen Bilimleri Enstitüsü, İstanbul.

Yıldızhan H (2018) Kent Meydanlarının Tasarım Yönünden İrdelenmesi: Isparta Kaymakkapı Meydanı Örneği. Yüksek Lisans Tezi, Süleyman Demirel Üniversitesi, Fen Bilimleri Enstitüsü, Isparta. 
